\title{
AWAKENING LOCAL TOURISM BASED ON INDISCHE ARCHITECTURE IN INDONESIA. CASE STUDY KAJOETANGAN KAMPONG HERITAGE OF MALANG
}

\author{
Wahyu Tyas PRAMONO* \\ Universitas Negeri Malang, Faculty of Social Sciences, Department of Geography, \\ Semarang Street 05, 65145, Malang, East Java, Indonesia, e-mail: wahyutyaspramono@ gmail.com \\ Swastika Dhesti ANGGRIANI \\ Universitas Negeri Malang, Faculty of Letters, Department of Fine Arts Education, \\ Semarang Street 05, 65145, Malang, East Java, Indonesia, e-mail: swastika.dhesti@fs.um.ac.id
}

\section{Nanda Harda Pratama MEIJI}

Universitas Negeri Malang, Faculty of Social Sciences, Department of Sociology Education, Semarang Street 05, 65145, Malang, East Java, Indonesia, e-mail: nanda.harda@ fis.um.ac.id

\section{Norsidah UJANG}

Universiti Putra Malaysia, Faculty of Design and Architecture, Department of Landscape Architecture, 43400, Serdang, Selangor, Malaysia, e-mail: norsidah@upm.edu.my

\section{Joko SAYONO}

Universitas Negeri Malang, Faculty of Social Sciences, Department of History Education, Semarang Street 05, 65145, Malang, East Java, Indonesia, e-mail: joko.sayono@ fis.um.ac.id

\begin{abstract}
Citation: Pramono, W.T., Anggriani, S.D., Meiji, N.H.P., Ujang, N., \& Sayono, J. (2021). AWAKENING LOCAL TOURISM BASED ON INDISCHE ARCHITECTURE IN INDONESIA; CASE STUDY KAJOETANGAN KAMPONG HERITAGE OF MALANG. GeoJournal of Tourism and Geosites, 35(2), 437-444. https://doi.org/10.30892/gtg.35223-670

Abstract: Kajoetangan or Kayutangan kampong heritage is a new tourist spot in Malang that emphasizes the empowerment of local communities in realizing settlement-based sustainable tourism that existed during the colonial era which was composed of dozens of Indische architecture in the late 19th to early 20th centuries. Kayutangan heritage villages are composed of settlements with a small size with access in the form of a small footpath combined with a mural and various outdoor plants. The houses in the area have not changed for nearly a hundred years, which have been passed down from generation to generation. Descriptive qualitative method is used in this research by combining the data obtained based on in-depth interviews, survey and combined with literature studies. Purpose of this research is to explore historical sequences and processes of sustainable tourism management controlled by local residents with financial assistance from various partners. The results of the study show that the role of local communities is quite positive in efforts to support tourists either by being directly or indirectly involved by building supporting facilities for core tourism such as culinary spots and souvenirs. Collaboration with several government agencies, universities and banks also makes the additions and directions in making and using additional facilities more structured.
\end{abstract}

Key words: heritage, colonial building, indische architecture, kajoetangan

\section{INTRODUCTION}

Kayutangan kampong heritage is located in the city of Malang, East Java Province, Indonesia which was formally inaugurated as one of the tourist destinations in 2018 by the Malang city government along with the Malang city tourism department. In general, this area is part of the CBD of Malang which is on the west side of Basuki Rahmat street in which connects the town square towards the city of Surabaya (capital province) in the north.

In general, the city of Malang itself has several spots for Dutch colonial resident settlements that were built in the early $20^{\text {th }}$ century (Bogaers and Ruijter, 1983; Sumalyo, 1995; Handinoto and Paulus, 1996), considering that Malang itself was officially established in 1914 after separating from the Pasuruan region. This city is a mountainous area flanked by Mount Bromo in the east with an altitude of 2329 meters, as well as Mount Arjuno (northwest), Semeru (southeast) and Kawi (southwest) (Schaik and Diessen, 1996). This city developed in the recent phase after colonial settlements developed in the early stages such as in Jakarta, Semarang and Surabaya which existed in the early $17^{\text {th }}$ to $19^{\text {th }}$ century (Handinoto and Paulus, 1996; Roosmalen, 2013). Malang area has similarities with Bogor (Colonial name: Buitenzorg) which is 60 kilometers south of Jakarta (Colonial name: Batavia) as the seat of the VOC government (Nederlands; Verenigde Oost Indische Compagnie), which was founded in 1602, as a trading organization in the East Indies (Budiharjo and Sidharta, 1997;

\footnotetext{
* Corresponding author
} 
Pramono et al., 2020). Then in 1799, this organization was officially disbanded and replaced by the Dutch kingdom directly due to the high number of corruption cases in the private company (Handinoto and Paulus, 1996; Pramono et al., 2020). Below, inside the (Figure 1), showed the location of Malang municipality, in the eastern part of Java island (red point).

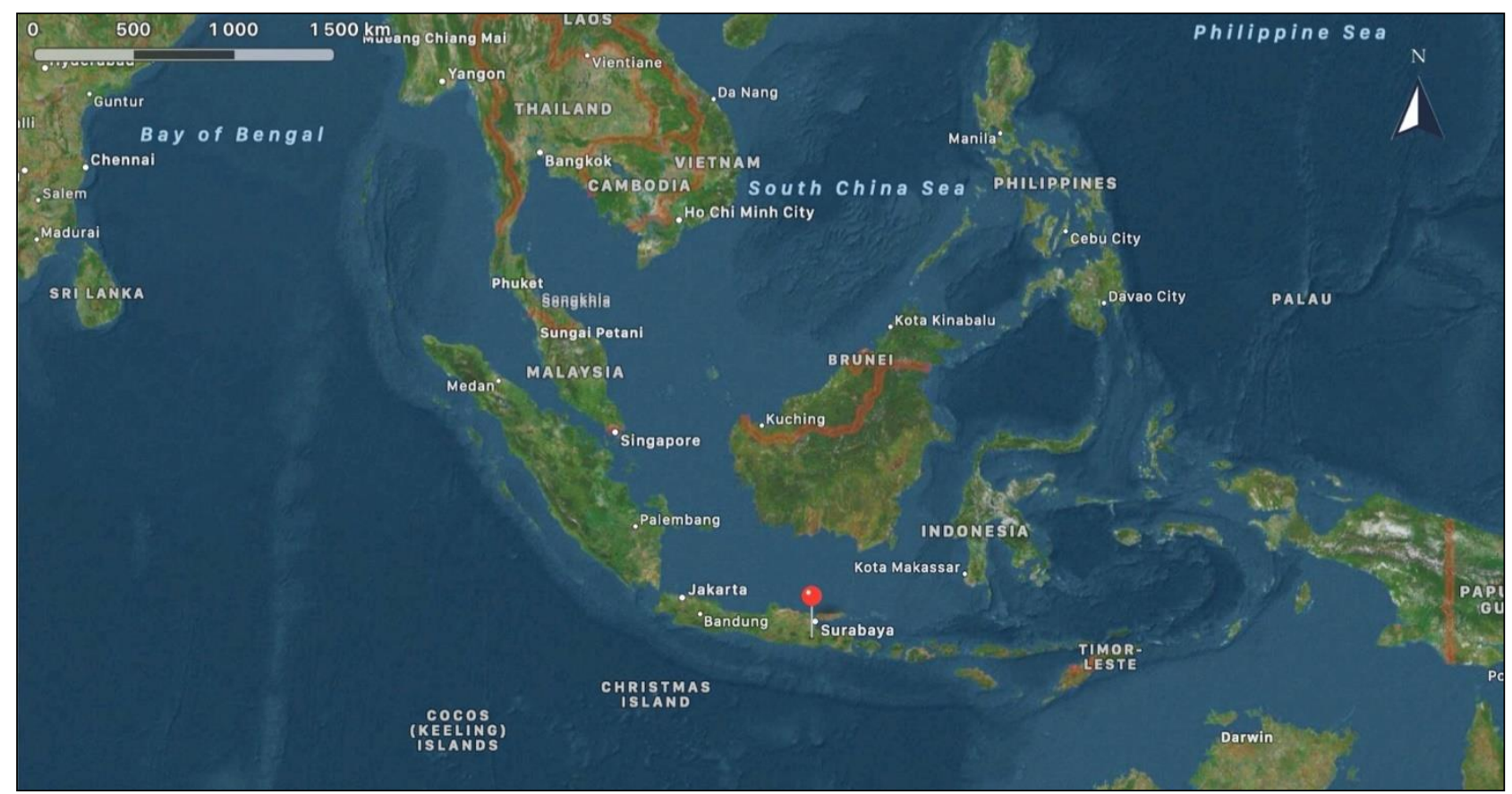

Figure 1. Malang is located $90 \mathrm{~km}$ in the south of Surabaya (the largest city in East India) (Source: iOS Maps, 2020)

Malang was seen as an ideal area in colonial times because it had a mild climate, so that many colonial settlements were built which were scattered in the areas of Buring Street, Idjen Boulevard, Tugu, Semeru Street, and Oro-Oro Dowo (Sumalyo, 1995; Schaik and Diessen, 1996; Handinoto and Paulus, 1996). This area is known as an elite area because of the size of the building which is quite large, with an Indische style (a combination of European elements in an ornament adapted to a tropical region with high rainfall), then has a large enough yard that is used for gardens with flowers and tropical fruits (Sumalyo, 1995; Marpaung, 2002; Handinoto and Paulus, 1996; Ching, 2008; Roosmalen, 2013).

Kayutangan area (the old Kajoetangan spelling) itself, it is part of the Oro-oro dowo which is then divided into two designations. The eastern part bordering Basuki Rahmat street was used for shops with Art Deco-style buildings in the late $19^{\text {th }}$ to early $20^{\text {th }}$ centuries (Akihary, 1990; Schaik and Diessen, 1996; Ching, 2008). The owners and residents were generally white Europeans. Meanwhile, the settlements in Kayutangan are dominated by local people (Pribumi which consist of Java and Madura) who occupied as worker class (Handinoto and Paulus, 1996; Laksono, 1985). Access to the Kayutangan settlement is more on narrow sidewalks with pedestrian access, and is different from the colonial settlements in the Buring region, and Idjen Boulevard which are designated for Dutch residents with high economic strata (Akihary, 1990; Sachari, 2007; Schaik and Diessen, 1996; Ching, 2008). Apart from being an area for recreational purposes, Malang is also developing because many plantations such as coffee and sugar cane were built, which later built several sugar factories such as the Krebet and Kebon Agung sugar factories which were once owned by the richest man in Southeast Asia of Chinese descent, Oei Tiong Ham between $19^{\text {th }}$ and $20^{\text {th }}$ centuries (Schaik and Diessen, 1996; Pramono et al., 2020). The colonial government itself divided the city area into specific loci based on ethnic background. Nationally, the social strata is divided into 3, namely the upper class which is filled by the Dutch as the holder of government control, the second strata is occupied by foreign immigrants from China, India and Arabia as the holder of the trade sector and indigenous groups or native people who play the lowest dominating position on agricultural sector (Koentjaraningrat, 2005; Pramono et al., 2020).

Kayutangan occupies 3 RW (Indonesian; Rukun Warga), namely 1, 9, and 10. Rukun Warga is a shared address system with RT (Indonesian; Rukun Tetangga) which was developed during the Japanese occupation, considering that not all houses in Indonesia have street numbers with a grid system. Some parts of the east, which are generally dominated by Art Deco buildings, (Ashihara, 1986; Shiryani, 1985; Budiharjo and Sidharta, 1997; Roosmalen, 2013) have now mostly undergone changes by demolishing old buildings and replacing them with new buildings that are intended for offices and shops. The old settlement is located on the inside which can be accessed through 2 doors on the east, two doors in the west, two doors in the north and two doors on the south side. Access to tourists can only be reached by walking along the existing corridors and enjoying old Indische-characterized buildings and some Jengki buildings which are taken from the Yankee word as the influence of the post-war modern style from America (Shirvani, 1985; Mulyandari, 2010; Roosmalen, 2013).

The three RWs in Kayutangan heritage village have at least 36 objects consisting of 20 buildings that were built during the colonial period for the purpose of settlements for local residents. The oldest building in Kayutangan was built in 1870 in an indische style which is still used today as a resident's house (Akihary, 1990; Ching, 2008; Roosmalen, 2013). The participation of various agencies in Kayutangan is mainly in the form of financial assistance which is realized by providing equipment such 
as garden lights, plants, flowers, directions board, ornaments, fences, murals, as well as detailed map containing objects that are highlighted in the kampong heritage of Kayutangan (Pendit, 2002; Howard, 2003).

Kayutangan is managed independently by local residents who are members of the Kayutangan tourism development group. They carry out various activities with partners from the government, banks, universities, and directly touch the implementation of the program and tourists who come to the location. Guidance from various parties as well as the public's willingness was discussed in a group discussion forum held before program implementation (Hadiwijoyo, 2012). Although this heritage village is classified as a new spot located in the city of Malang, the progress and number of visitors who come to kampong heritage Kayutangan from time to time have increased (exceptions in mid-2020 due to the Covid-19 pandemic).

This is in line with the development of heritage tourism objects in Indonesia in particular and in Asia in general (O’Hare,1997; Gordon, 2018; Macbeth, 2021), such as several building complexes in Ho Chi Minh City, Vietnam with French colonial building style, Yangon, Myanmar old city which has many British colonial buildings, Malacca by the Dutch and Portuguese in Malaysia, Penang and Phuket with British colonial buildings and Spanish colonial buildings in Vigan City, Philippines (Wood, 1980; Taylor, 2015; Yotsumoto and Vafandari, 2021). Data collection of several important objects that are highlighted is very necessary, considering the concentration of historic buildings in the Kayutangan settlement area is quite high. Even though in the middle of the threat, the function of the building was changed to a new, wider and more modern building. At the end, purpose of this research is to explore historical sequences and processes of sustainable tourism management controlled by local residents with financial assistance from various partners both public and private sectors.

\section{MATERIAL AND METHODS}

Descriptive qualitative method is used in this research by combining the data obtained based on in-depth interviews, survey and combined with literature studies. The literature used has a reference to the history of the development of the city of Malang in general, and is narrowed to the Kayutangan area, this is because the city of Malang is a municipality in East Java Province which was founded in the early 1900s, so that when compared to coastal areas, such as Jakarta and Semarang and Surabaya, it was considered as the latest development (Bogaers and Ruijter, 1983; Colombijn and Berwegen, 2005; ). Sources mainly came from old literature material from the Netherlands and recent development by Indonesian writers. In-depth interviews were conducted with sources from various parties, including the Malang city tourism office, as well as several important figures in the kampong Kayutangan heritage. The results of the literature study and interviews were then analyzed and represented using tabular and descriptive data (Denzin and Lincoln, 2009; Kusmayadi and Sugiarto, 2000). The data obtained includes the history of the buildings in Kayutangan and their functions at that time, to their current functions and other changes including the layout (landscape) and development as a heritage village which began in early 2018, with support from the local government through the tourism department (Hadiwijoyo, 2012; Roosmalen, 2013). The combination of literature studies and in-depth interviews is used to increase the completeness of information and correct any discrepancies between the results in the field and the available literature. Although literature study is quite helpful, it needs to be sorted into a more specific section, considering that the heritage area in Malang study is very broad and includes several different functions (Hadiwijoyo, 2012). As shown in the illustration below (Figure 2), there are at least three stages in the research, which are consist of preliminary process (literature); survey and in-depth interview; analyzing and reporting the results.

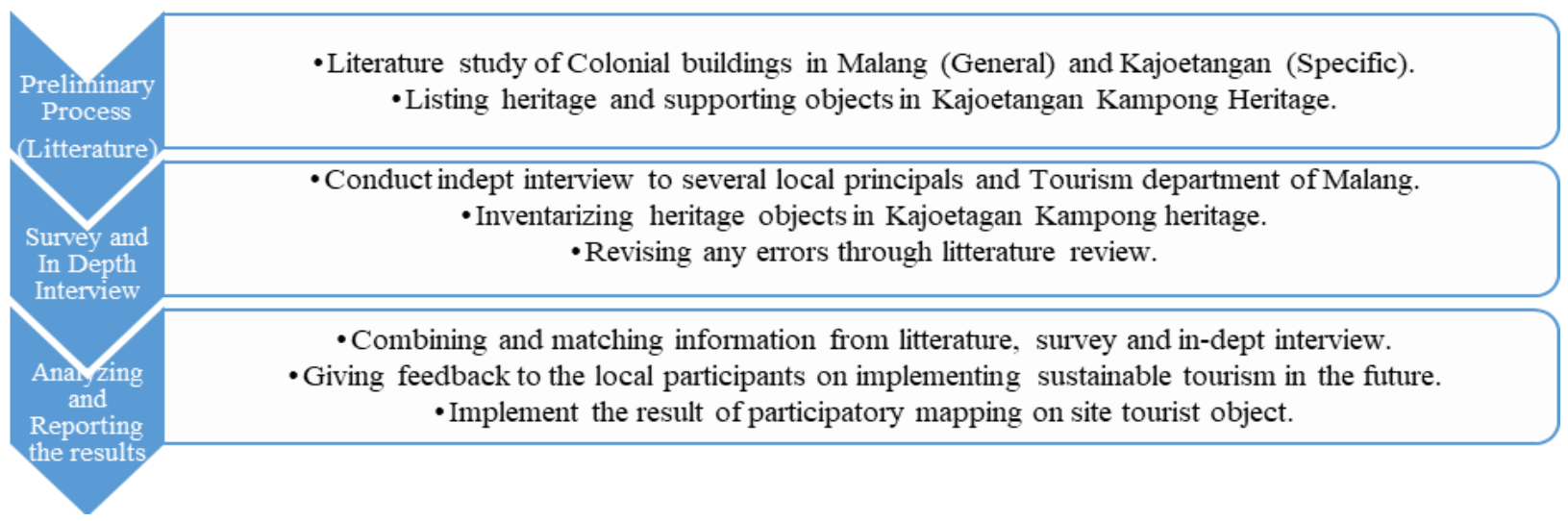

Figure 2. Data Analysis Process

\section{RESULTS AND DISCUSSIONS}

Malang is a city that has many colonial buildings in Indonesia, both which function as government offices, public facilities, or private buildings in the form of settlements (Birks et al.,1989; Akihary, 1990). One of the several colonial building spots is Kayutangan, with a heritage village inside. Kayutangan kampong heritage can be classified as a cultural landscape tourism object which is one of many other examples in Indonesia due to historical interactions in the past (Appadurai, 1986; Samsudin, and Maliki, 2015; Andhika and Putra, 2020), especially in the colonial era in the Dutch East Indies.

Kampong heritage Kayutangan includes several mainstay objects and supporting objects. Mainstay objects generally have a strong historical value and their buildings were built earlier than other parts. Kayutangan itself comes from the Javanese language which means (kayu; wood) and (tangan; hands) because in the past times, the area had a tree whose branches resembled hands (Schaik and Diessen, 1996; Akihary, 1990; Roosmalen, 2013). As a whole, Kayutangan area is the initial 
CBD of Malang city which has complete public and trade facilities, although now the trade centers are scattered in several points where visitors can find modern shopping centers. In general, the Kayutangan area is north of the city square surrounded by colonial complex offices which centered in the Tugu area (Sumalyo, 1995). Important objects found in Kayutangan include the Kayutangan Cathedral and several Art Deco-style shopping complexes that still exist today. Conical to the Kayutangan heritage village area, the scope is narrower and is devoted to the part which is now still inhabited for generations by local residents. Most of the residents of Kayutangan heritage village are workers who migrated to Malang in the late $19^{\text {th }}$ and early $20^{\text {th }}$ centuries (Bogaers and Ruijter, 1983; Schaik and Diessen, 1996).

There are several focused objects in Kajoetangan kampong heritage namely Namsin house, Jengki house, house 1870, Rindu house, Chimney house, Nyi Aisyah house, Mbah Ndut house, rumah Kartini house, Dawet ireng house, Mr. Sutikno house, Mr. Sakirman house, Old house, Thousand stairs, Gubuk ningrat, Jacoeb house, Nyi Abas Akub galery, Punden house, Mr. Udin house, Mr. Eko galery, Ranuatmodjo house, Old mosque, Jamu house, and AEO galery.

Rumah 1870 is the oldest house in the kampong heritage of Kayutangan. This house has an indische-style exterior design, equipped with interior ornaments or furnishings that are still maintained as they were at that time. The colors used as external and internal paints are still the same, with a predominance of white and gray. Visitors can see the history of the house and see the interior with the owner's permission. This house is located in the middle of the Kayutangan settlement, besides that there are also photos and books that contain the history of Malang in general, including the Oro-oro dowo area, Buring, Idjen Boulevard, Semeru, Tugu, and Kayutangan (Handinoto and Paulus, 1996; Roosmalen, 2013). This house is similar to the Gubuk Ningrat, which is located not far from the place, but the state of the Gubuk Ningrat is better maintained.

Meanwhile, Namsin house, is one of the mainstay spots owned by the Kayutangan kampong heritage. This house is directly opposite the main street and the entrance to the heritage village in the east. Namsin house was once used as a shop, and was combined with a residence. Visitors can see the intact architecture that was built in the early $20^{\text {th }}$ century. However, it is not every day that Namsin house is open to the public, so coordination is required with the manager to be able to have a closer look at the interior side. The interior is still authentic as it is, dominated by furniture such as cupboards, tables and chairs made of teak and rattan. There is also furniture that is still intact and has high historical value. The building style also uses Indische with a two-story arrangement connected by wooden stairs. At the top there is a long table with chairs and wide windows, typical of the tropics (Mulyandari, 2010; Handinoto and Paulus, 1996). The owner of Namsin's house was originally a Dutch trader, who later experienced repatriation or repatriation of all personnel and Dutch descent from Indonesia after the postIndependence in 1945, the photograph of Rumah Namsin can be seen on Figure 3(b). As a result, all assets such as houses had to be abandoned by the owner, and this is very common not only in Malang but also in all major cities in Indonesia such as in Medan, Jakarta, Bandung, Surabaya, Semarang, Palembang, Ujung Pandang and Surakarta (Ching, 2008; Roosmalen, 2013).

The Punden house also has an indische style, the furniture inside has a high historical value and is still neatly stored. Visitors can take pictures in front of or go inside the house to see the interior of the indische building interspersed with a brief interview with the owner of the house they meet. In general, home owners who are met in Kayutangan Heritage Village will be very happy and voluntarily provide information to visitors who come, especially if the tourists visiting are domestic tourists. For foreign tourists, you can contact a tour guide service who translates into English. This is like the implementation of tourism villages in Bali (Urry and Larsen, 2012; Andhika and Putra, 2020), where people participate in tourism promotions and interact directly with tourists, such as in Panglipuran Tourism Village in central Bali (Putra, 2019).

There are also two very popular galleries in Kayutangan, namely AEO Gallery and Abas Akup Gallery, both of which have different specifications, Abas Akup Gallery focuses more on painting, so visitors can paint individually, or buy several existing collections. Meanwhile, the AEO gallery is more on decorating antiques for photographic purposes. Antiques that are lined up in front of the Indische-style house include several antic televisions, suitcases, old-bicycles and petromax lamp ornaments that existed in the 19th century. Here visitors can take photos independently or flash photo services on site.

For other main objects, the things offered are quite the same, namely the indische building style which is still maintained today. Based on interviews with tourists, especially local tourists, they visited Kayutangan kampong heritage for reasons of wanting to know more after obtaining information from social media. Although most of them are more interested in doing photography and rent some costumes provided by local people to take pictures in indische buildings without wanting to know more about the history of each object. This has similarities with visitors in several historical places in the world, such as in Europe, many visitors are more interested in objects of their architectural beauty without wanting to know more about their history (Burhalis, 2004; Monroe, 2003; Pitana, 2009; Park and Santos, 2017).

In addition, there are several support facilities, either in the form of facilities provided by local people or with banking cooperation such as chairs and murals for photography. The addition of this independent facility shows that the development of cultural tourism that emphasizes the cultural landscape, especially historical areas, will stimulate the emergence of entrepreneurship, especially government support, institutions providing capital in line with what was initiated by local communities (Conzen, 2004). With this the concept of sustainable tourism will be easier to achieve and will continue to develop in a positive direction (Shaw and Shaw, 1999; Samsudin and Maliki, 2015; Astawa et al., 2019). In tourism management, management is carried out independently by joining a tourism awareness group (Indonesian; Kelompok Sadar Wisata or abbreviated as POKDARWIS) consisting of local residents. They have the task of carrying out an inventory of historical buildings in Kayutangan. Then they tracked ownership from generation to generation which would later be needed for complete information from each existing building.

This tourism awareness group has the full support of the city government and the tourism office to create a sustainable heritage village. This is very important in the management of tourist attractions to synergize with many related elements to create sustainability and ultimately to the convenience of tourists themselves (Baud-Bovy and Lawson, 1998; Domosh, 2004). 
Kayutangan management, which is directly supported by the tourism office, has become a cultural tourism package that is synergistically carried out in the city of Malang, either in association with the Idjen Boulevard, Celaket, or Jodipan village. Although specifically for the Kayutangan heritage village, tourists will come in direct contact with the residents, and this cannot be found in the Idjen Boulevard or Celaket areas, which are now occupied as luxurious residential buildings, restaurants, cafes, and guest houses, so it is not maybe tourists can dig up detailed information on the current owner.

In addition to information about the number of points highlighted in the social media accounts of the Kayutangan kampong

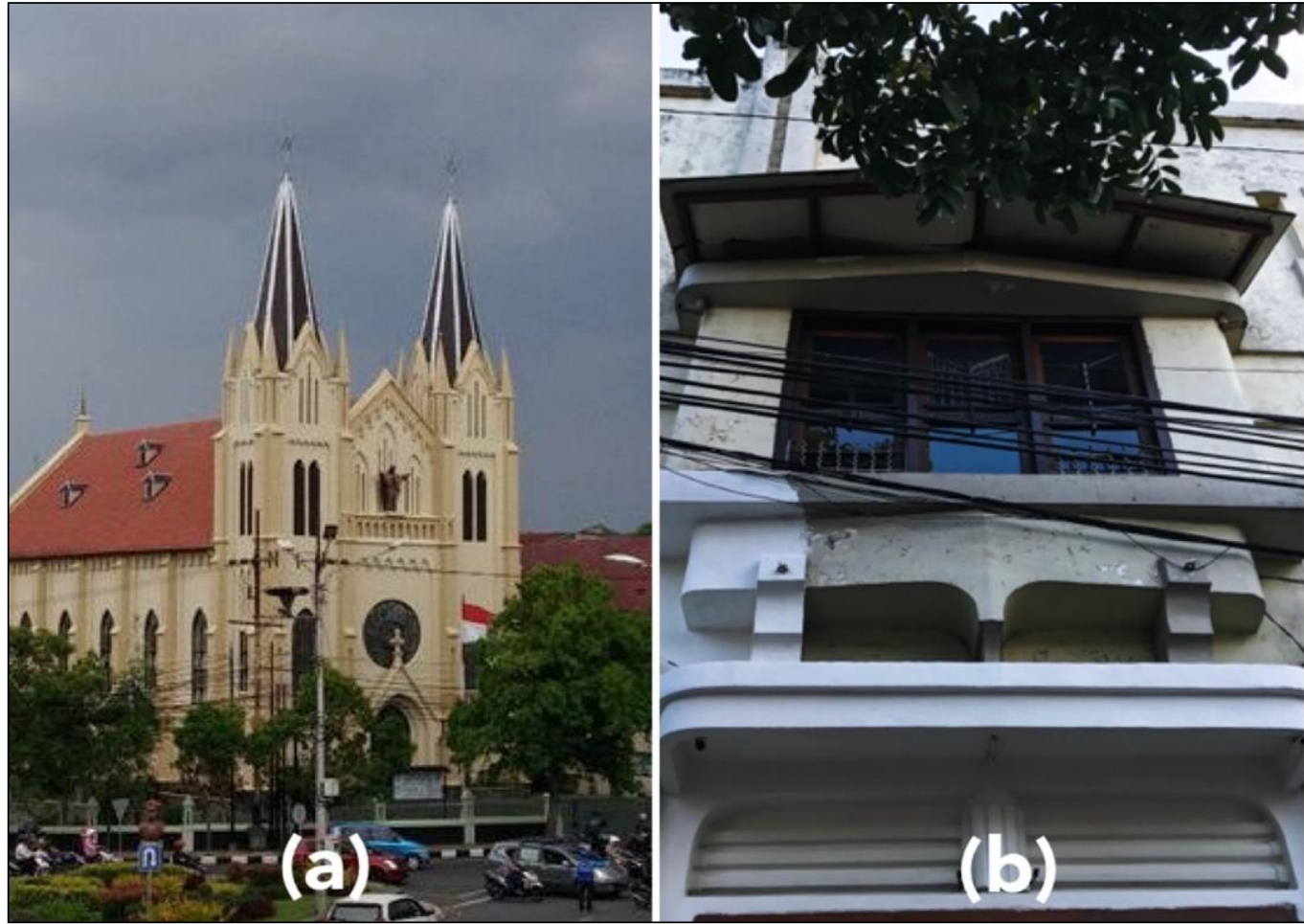

Figure 3. Figure (a) Kayutangan Church is a Catholic church built in 1905 as high as 33 meters by the Dutch architect Marius J. Hulswit during the colonial rule in Indonesia; Figure

(b) Namsin house or Rumah Namsin photographed from the front fascia of Jalan Basuki Rahmat heritage. Some of the company's CSR collaborations also help make plans to make it easier for visitors to recognize these tourist villages main objects. Previously, the map for pointing objects has been made two times in collaboration with banks and universities, but because it is only made using illustrations, the effectiveness of the map is reduced, so a location map is made that is taken from the image to give a real impression, and translated into the language of art design for splay and remove distracting objects that are less prominent on the map. The following is an illustration obtained from the conversion.
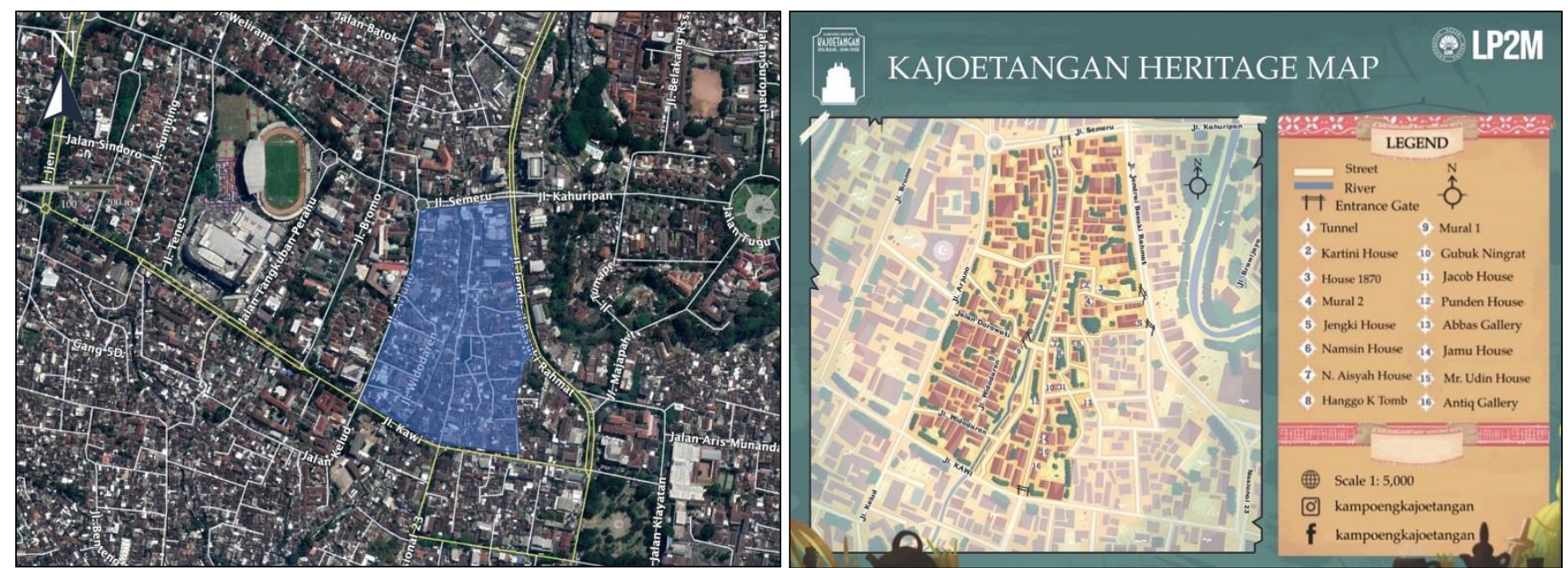

Figure 4. (left) inside the blue shade is Kayutangan kampong heritage, surrounded by artery streets in Malang City, (right) The new pamphlet in

Kayutangan kampong heritage after collaboration with Malang State University (Source: Google Earth TM and CorelDRAW, 2020)

The fee or entrance ticket for visitors is set at 5000.00 IDR or the equivalent of US\$ 0.3 for one visitor. There are 7 entrances that can be accessed from various main roads around the site. Prices which are quite cheap in some cases have a positive impact on the promotion of new tourist objects, when compared to those that are more well-known and have a fairly high maintenance value (Tosun and Jenkins, 1996; Yang and Wall, 2009; Munroe et al., 2014). Although, only the entrance from the east provides the most complete facilities, such as pamphlets containing points of objects that may be of interest to tourists. On normal days, generally daily visitors can reach 250 to 300, while on holiday days it can reach 500 visitors per day. However, during 2020, starting in early March, activities in heritage villages began to decline and even locked down for several weeks. Below are the main objects in the Kayutangan kampong heritage. 
The profit obtained from retribution is then managed by the tourism awareness group to increase additional facilities or maintenance of parts that need to be addressed. In the future, additional parks and cleaning of several spots so that they look more comfortable will also be carried out, although in some cases there are still obstacles in the cooperation or coordination of home owners with tourism awareness groups and local RT's principal. It should be noted that not all Kayutangan areas are included in the management of Kayutangan kampong heritage. Even though in some parts there are public objects that have very historical value such as shopping complexes, offices and churches, the coverage of heritage villages is only limited to residential groups on the western part of Basuki Rahmat street with the exception of the Toko Oen restaurant area which has become one of the culinary tourism icons that was established since the Dutch colonial period. The comfort of tourists is a top priority,

Table 1. Objects in Kampong Heritage Kayutangan and their status as heritage site or non-heritage site

\begin{tabular}{|l|l|}
\hline \multicolumn{1}{|c|}{ Objects } & \multicolumn{1}{c|}{ Status } \\
\hline Namsin House & as heritage site (not all day opened) \\
\hline Penghulu House & as heritage site (not all day opened) \\
\hline Jengki House & as heritage site (all day opened) \\
\hline 1870 House & as heritage site (all day opened) \\
\hline Gubuk Ningrat & non-heritage (all day opened) \\
\hline Jamu House & as heritage site (opened with permission) \\
\hline Jacob House & additional spot-non-heritage \\
\hline Tangga Seribu & non-heritage (all day opened) \\
\hline Nyi Abas Akub Galery & as heritage site (all day opened) \\
\hline Rumah Punden & as heritage site (all day opened) \\
\hline AEO Galery & non-heritage (all day opened) \\
\hline Old Mosque & as heritage site (not all day opened) \\
\hline Ranuatmodjo House & as heritage site (opened with permission) \\
\hline Mr Udin House & F and B facility \\
\hline Dawet Ireng & non-heritage (all day opened) \\
\hline Nyi Aisyah House & non-heritage (all day opened) \\
\hline Chimney House & as heritage site (not all day opened) \\
\hline Kartini House & non-heritage (all day opened) \\
\hline Sukirman House & F and B facility \\
\hline Mbah Ndut &
\end{tabular}

be used more flexibly because it combines geographical elements and combines it with animation to attract visitors to use it. so that supporting elements are needed in the Kayutangan heritage village. One of them is that the existence of this tourist village has stimulated the emergence of food and beverage businesses available in the tourist complex that carry traditional, authentic or modern concepts such as cafes. On certain special events, Kayutangan Village also holds a carnival with a colonial concept. Visitors can also rent Dutch colonial or Javanese costumes in the villages and can take pictures at several spots that they want. This is of course a special attraction or it can be said as a unique characteristic that is only obtained from the Kayutangan kampong heritage. Observers of tourism, history and architecture were also invited to collaborate in several forums held between tourism awareness groups and cooperation agencies, by providing future directions that had a positive impact. One of them is regarding the concept of a garden, signboards, information boards, lamps, chair styles, and paint used in building maintenance, as authentic as possible. In addition to information about the number of points highlighted in the social media accounts of the Kayutangan heritage village. Some of the company's CSR collaborations also help make plans to make it easier for visitors to recognize these tourist villages. In 2020, the State University of Malang will revitalize the map so that it can

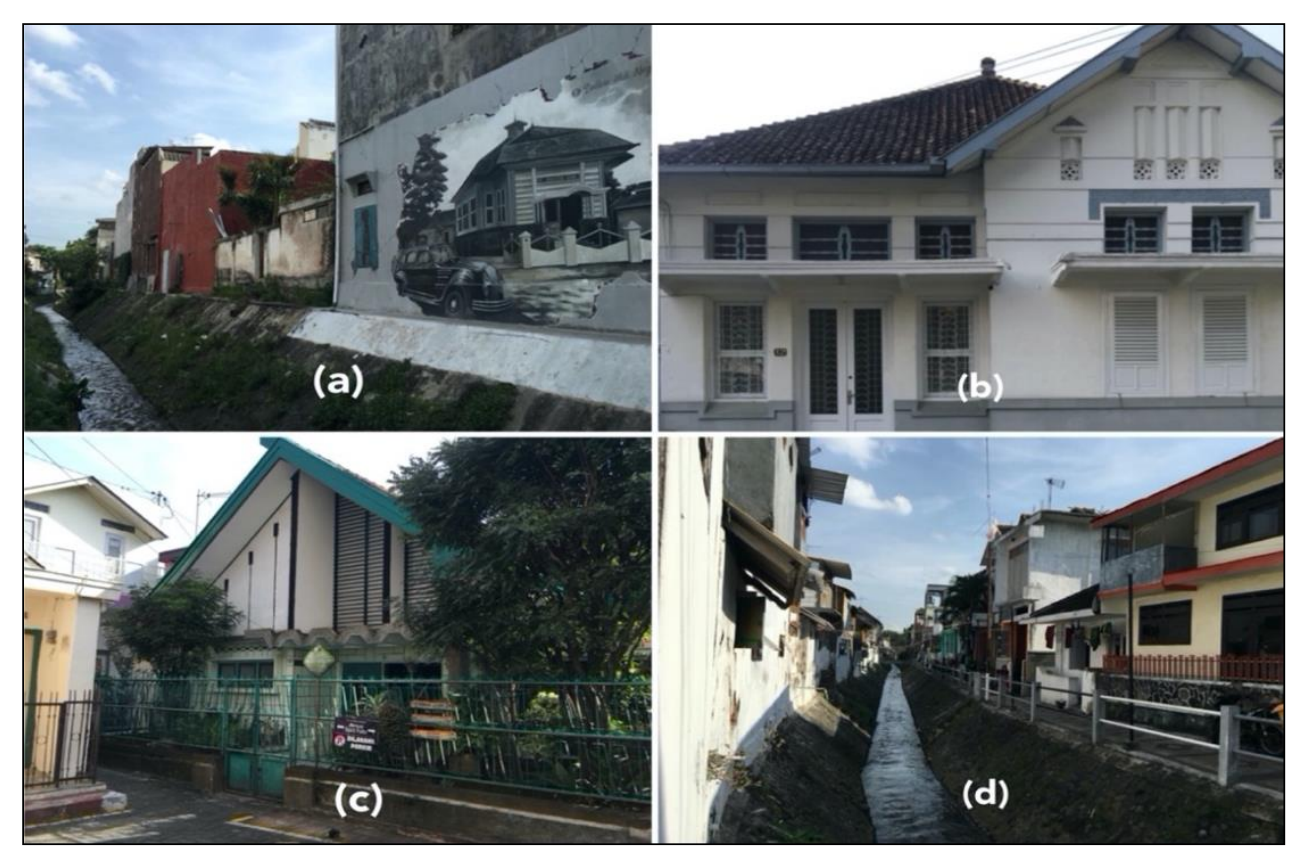

Figure 5. From (a) to (d); (a), a mural in Kayutangan Kampong Heritage as collaboration between the local and Bank of Indonesia (formerly known as De Javasche Bank) as a donor in tourism program; (b), Indische house with high ceiling and roof, large windows and doors for air circulation in tropical condition; (c), Jengki house in Kayutangan Kampong Heritage as awakening of freedom expression in architecture style, derived from United States of America which popular from 1950s to 1960s; (d), Kayutangan canal, with dense houses in Kampong heritage

During the one-year development of the kampong heritage Kayutangan, there have been many significant advances, especially in the completeness of the facilities needed to support tourist objects. In the case of the city of Malang, the development of the Kayutangan heritage village is motivated by the success of the Jodipan color village, which was first established. The local party, in cooperation with the city government, then initiated the idea of a heritage village, because of its uniqueness, which has a larg colonial residential density in residential areas. However, when compared to other parts of Malang, the Kayutangan area is not an elite area with large settlements of greater importance (Sachari, 2007). 
The challenge that may be faced in the development of the Kayutangan kampong heritage is the loss of ownership due to the transfer of the building to a new owner, who then renovates the building which has a more modern design. As a result, the number of buildings with historical value is decreasing, plus the environment has become less cohesive in terms of building style, and this has started to appear in the Kayutangan kampong heritage in 2020.

\section{CONCLUSION}

The collaboration of the kampong heritage Kayutangan is not dominated by top down government regulations, but is also combined with bottom up by educating local residents to participate directly in efforts to realize sustainable tourism, even though in early 2020, with the Covid-19 pandemic, the number of visitors decreased drastically and the progress of upgrading the facility is slower.Improved facilities such as the addition of photo spots for tourists in the form of murals and parks add to their own attractiveness and uniqueness, especially for local tourists targeting teenage ages.

In addition, the use of social media, especially Instagram with insta-story features or photo uploads, can attract local tourists to visit locations that are open from 7 am to the evening. The tourists are more interested in photo spots in the form of colonial buildings and existing properties, murals, and man-made gardens, rather than tourists who want to know the complete history of Kayutangan. Information about the building is already available in front of the important site, although the information obtained is very limited. This can be overcome by using the internet independently or reading history books available at the Gubuk Ningrat in the Kayutangan heritage complex.

In the future, the collaboration of various parties is expected to encourage the realization of sustainable tourism and can attract tourists to visit the city of Malang, which has long been known as a transit city before taking a tour to Batu which is located approximately 20 kilometers in the western part of Malang. Even local residents through youth groups are also quite enthusiastic in supporting tourism activities as well as participating in data directly or indirectly by providing several supporting facilities such as cafeterias and souvenir outlets.

\section{Acknowledgements}

The research was conducted by PNBP (Indonesian: Penerimaan Negara Bukan Pajak) grant from Universitas Negeri Malang and Ministry of Education and Culture Republic of Indonesia 2020.

\section{REFERENCES}

Andhika, I.M., \& Putra, I.D.G.A.D. (2020). Reinvigorating Cultural Landscapes for Cultural Tourism in Bali. GeoJournal of Tourism and Geosites, 33(4spl), 1462-1469. https://doi.org/10.30892/gtg.334spl03-594

Akihary, H. (1990). Architectuur en Stedebouw in Indonesie 1870-1970 [Architectur and Urban Planning in Indonesia 1870-1970]. De Walburg Pers, Zuthpen, The Netherlands.

Appadurai, A. (1986). The social life of things: commodities in cultural perspective. Cambridge University Press, Cambridge.

Ashihara, Y. (1986). Perancangan Eksterior dalam Arsitektur. [Exterior Planning on Architecture]. Penerbit Abdi Widya, Bandung, Indonesia.

Astawa, I.P., Sukawati, T.G.R., \& Sugiartha, I.N.G. (2019). Developing a harmonious culture-based sustainable event model in Bali Tourism Village. GeoJournal of Tourism and Geosites, 25(2), 446-462. https://doi.org/10.30892/gtg.25214-372

Budiharjo, E. (1997). Arsitektur Pembangunan dan Konservasi.[Architectur development and Conservation]. Djambatan, Jakarta, Indonesia. Baud-Bovy, M., \& Lawson, F. (1998). Tourism and Recreation: Handbook of Planning and Design. Butterworth Heinemann Press, Oxford, UK. Birks, H.H., Birks, H.J.B., Kaland, P., \& Moe, D. (1989). The cultural landscape: Past, present and future. Cambridge University Press, Cambridge, UK.

Bogaers, E. \& Ruijter, P.D. (1983). Ir. Thomas Karsten en de stadebouw in Nederlands Indie 1915-1940. [Ir. Thomas Karsten and the city building in East India 1915-1940]. Planologisch en Demografisch Instituut, Universiteit van Amsterdam, Amsterdam, The Netherlands.

Burhalis, D. (2004). Tourism Management Special Issue: The Competitive Destination. University of Westminster, London, UK.

Ching, F.D.K. (2008). Arsitektur: Bentuk, Ruang dan Tatananya. [Architecture: Shape, Space and Arrangement]. Erlangga Press, Jakarta, Indonesia.

Colombijn, F., \& Berwegen, M. (2005). Kota lama, kota baru. Sejarah kota-kota di Indonesia sebelum dan setelah kemerdekaan [The history of the Indonesian city before and after independence]. Ombak, Yogyakarta, Indonesia.

Conzen, M. (2004). Cultural landscape in geography. In N. Smelser \& P. Bates (eds), International encyclopaedia of the social and behavioural sciences, 3086-3092, Elsevier, New York.

Denzin, \& Lincoln. (2009). Handbook of Qualitative Research. Pustaka Pelajar Press, Yogyakarta, Indonesia.

Domosh, M. (2004). Cultural landscape in environmental studies. In N. Smelser \& P. Bates, (eds), International Encyclopaedia of the Social and Behavioural Sciences, 3081-3086, Elsevier, New York.

Gordon, J.E. (2018). Geoheritage, geotourism and the cultural landscape: enhancing the visitor experience and promoting geoconservation. Geosciences,8(136), 1-25. https://doi.org/10.3390/geosciences8040136

Hadiwijoyo, S.S. (2012). Perencanaan Pariwisata Perdesaan Berbasis Masyarakat (Sebuah Pendekatan Konsep). [Community Based Rural Tourism Planning (A Concept Approach)]. Graha Ilmu Yogyakarta, Indonesia.

Handinoto, S., \& Paulus, H. (1996). Perkembangan kota dan arsitektur kolonial Belanda di Malang [City development and Colonial architecture in Malang]. Andi, Yogyakarta, Indonesia.

Howard, P. (2003). Heritage Management, Interpretation, Identity. London-New York: Continuum.

Koentjaraningrat. (2005). Pengantar Antropologi II, Pokok-Pokok Etnograf. [Introduction of Anthropology II, Basic Ethnography]. Rineka Cipta, Jakarta, Indonesia.

Kusmayadi, \& Sugiarto, E. (2000). Metodologi Penelitian dalam Bidang Kepariwisataan. [Research methodology on Tourism]. Gramedia Pustaka Utama, Jakarta, Indonesia.

Laksono. (1985). Tradisi dalam Struktur Masyarakat Jawa: Kerajaan dan Perdesaan. [Tradition in Javanese Community Structure: Kingdom and Rural Area]. Gadjah Mada University Press, Yogyakarta, Indonesia.

Marpaung, H. (2002). Pengetahuan Kepariwisataan. [Tourism Knowledge]. Alfabeta, Bandung, Indonesia.

Macbeth, J. (2021). Archeology and tourism; touring the past. Journal of Heritage Tourism, 16(1), 118-119. https://doi.org/10.1080/ 17438773 X.2020.1822623 
Monroe. (2003). Pricing Making Profitable Decision. The Mc Graw Hill Companies, New York.

Munroe, D.K., McSweeney, K., Olson, J.L., \& Mansfield, B. (2014). Using economic geography to reinvigorate land-change science. Geoforum, 52, 12-21. https://doi.org/10.1016/j.geoforum.2013.12.005

Mulyandari, H. (2010). Pengantar Arsitektur Kota. [Introduction of City Architecture]. Andi, Yogyakarta, Indonesia.

O'Hare, D. (1997). Interpreting the cultural landscape for tourism development. Urban Design International, 2(1), 33-54. https://doi.org/ 10.1057/udi.1997.5

Park, S., \& Santos, C.A. (2017). Exploring the tourist experience. A sequential approach. Journal of Travel Research, 56, 16-27. https://doi.org/10.1177/0047287515624017

Pendit, N.S. (2002). Ilmu Pariwisata. [Tourism Science]. Pradnya Paramita, Jakarta, Indonesia.

Pitana, I. (2009). Pengantar Ilmu Pariwisata. [Introduction to Tourism Science]. Andi, Yogyakarta, Indonesia.

Pramono, W.T., Insani, N., Kriswidyaningrum, E.V., \& Khakim, M.N.L. (2020). May. Waiting for extinct, neglected precious heritage sites; case study of little Tiongkok lasem. In IOP Conference Series: Earth and Environmental Science, 485(1),012067). IOP Publishing. https://doi.org/10.1088/1755-1315/485/1/012067

Putra, I.D.G.A.D. (2019). The Impact of dynamic land-use and spatial planning policies on the traditional village and architecture in tourism villages in Gianyar Bali. Bhumi: Jurnal Agraria dan Pertahanan, 5(3), 34-41. https://doi.org/10.31292/jb.v5i3.388

Roosmalen, K.M.V. (2013). Confronting bulit heritage; Shifting perspectives on colonial architecture in Indonesia. ABE Journal [online]. http://journals.openeedition.org/abe/372; https://doi.org/10.4000/abe.372

Sachari, A. (2007). Budaya Visual Indonesia: membaca makna perkembangan gaya visual karya desain Indonesia abad 20. [Indonesian Visual Culture: reading the meaning of the development of the visual style of Indonesian design works in the 20th century]. Erlangga, Jakarta, Indonesia.

Samsudin, P.Y., \& Maliki, N.Z. (2015). Preserving cultural landscape in homestay program towards sustainable tourism: brief critical review concept. Procedia-Social and Behavioral Sciences, 170, 433 - 441. https://doi.org/10.1016/j.sbspro.2015.01.004

Schaik, A.V., \& Diessen, J.R.V. (1996). Malang Beeld van een stad. [Malang; image of a city]. Asia Maior. The Netherland.

Shaw, B., \& Shaw, G. (1999). Sun, sand and sales: enclave tourism and local entrepreneurship in Indonesia. Current Issues in Tourism, 2(1), 68-81. https://doi.org/10.1080/13683509908667844

Shirvani, H. (1985). The Urban Design Process. Van Nostrand Reinhold Company, New York.

Sumalyo, Y. (1995). Arsitektur Kolonial Belanda di Indonesia. [Dutch Colonial Architecture in Indonesia]. Gadjah Mada University Press, Yogyakarta, Indonesia.

Taylor, K. (2015). Cities as cultural landscapes. In F. Bandarin \& R. van Oers (eds.), Reconnecting the City: The Historic Urban Landscape Approach and the Future of Urban Heritage, 179-202, Wiley-Blackwell, Oxford, UK.

Tosun, C., \& Jenkins, C.L. (1996). Regional planning approaches to tourism development: the case of Turkey. Tourism Management, 17(7), 519-531. https://doi.org/10.1016/S0261-5177(96)00069-6

Urry, J., \& Larsen, J. (2012). The tourist gaze 3.0, 3rd ed, SAGE Publications, London, UK.

Wood, R.E. (1980). International tourism and cultural change in Southeast Asia. Economic Development and Cultural Change, 28(3), 56181. https://doi.org/10.1086/451197

Yang, L., \& Wall, G. (2009). Ethnic tourism: a framework and an application. Tourism Management, 30, 559-570. https://doi.org/10.1016/j. tourman.2008.09.008

Yotsumoto, Y., \& Vafandari, K. (2021). Comparing cultural world heritage sites and globally important agricultural heritage systems and their potential for tourism. Journal of Heritage Tourism, 16(1), 43-61. https://doi.org/10.1080/174387X.2020.1758116

***Map of Malang, Indonesia. Google Earth. (2020). https://www.google.com/intl/ms/earth/

***Map of Java Island, Indonesia. iOs Maps. (2020). https://www.apple.com/maps/

Article history: Received: 30.11.2020 Revised: 14.03.2021 Accepted: 30.04.2021 Available online: 24.05 .2021

